\title{
Quality monitoring for a water reclamation system in a
}

\section{mandarin orange canning factory}

Dan Wu ${ }^{1}$, Yin Chu ${ }^{1}$, Jian-Chu Chen ${ }^{1 *}$, Ji-Guang Hong ${ }^{2}$, Hai-Feng Gao ${ }^{3}$, Zhongxiang Fang ${ }^{1,4}$, Lei Shen ${ }^{1}$, Meng-Nan Lin ${ }^{1}$, Dong-Hong Liu ${ }^{1}$ Xing-Qian Ye ${ }^{1}$

${ }^{1}$ College of Biosystems Engineering and Food Science Zhejiang University, Hangzhou 310029, China

${ }^{2}$ Xiangshan Huayu Food Co. Ltd., Xiangshan Ningbo 315700, China

${ }^{3}$ Hangzhou HuaQi Water Treatment Equipment Co. Ltd., Hangzhou 310012, China

${ }^{4}$ School of Agriculture and Food Sciences, The University of Queensland, Brisbane, Qld 4072 , Australia

Authors. Tel/fax.: +86-8898-2287(Wu.D.,Chu Y.,Chen J.C.,Liu D.H.,Fang Z, Lin M.N.,Ye X.Q), +86-6572-3550(Hong J.G), +86-8775-7188(Gao H.F)

E-mail address: processing@zju.edu.cn(Wu.D),673340359@qq.com(Chu Y.), jc@zju.edu.cn(Chen

J.C.), dhliu@zju.edu.cn(Liu D.H.), 7869400@qq.com(Lin M.N.), psu@zju.edu.cn(Ye X.Q),

fzx@zju.edu.cn(Fang Z ),hjiguang@mail.nbptt.zj.cn(Hong J.G), sale@ hzhuaqi.com(Gao H.F)

Abstract: To conserve water in the mandarin orange canning industry, a water reclamation system was designed for a production scale of $50 \mathrm{~kL} / \mathrm{h}$. The discharged water from mandarin transportation using a conveyor belt was collected in a pool, chlorinated, filtered by active carbon and UV-sterilized. This water was then reused for the processes of segmenting, transportation, and washing after alkaline solution treatment. The water quality had been monitored during the water reclamation. The results showed that the reused water quality was improved by the system and the main physicochemical properties and sensory index conformed to the requirements of Chinese National Standard GB5749 except the index of chemical oxygen demand. The reused water contained about $0.4 \mathrm{ppm}$ of 
chlorine and $10 \mathrm{ug} / \mathrm{mL}$ of pectin. The total bacterial count was $\leq 10 \mathrm{CFU} / \mathrm{mL}$ and no E. coli were detected. The seasonal production monitoring results showed that the quality of disposed water from this system remained stable. This technology might be useful for water reclamation in other fruit processing plants.

Keywords: Mandarin orange canning, Water reclamation, Water quality monitoring

\section{Introduction}

Although water is ubiquitous, only about $0.4 \%$ is suitable for human consumption. (U.N. Water Development and Management, 1978). A report from the Committee of Environment and Development of the World in 1988 claims that water is replacing petroleum as a valuable commodity and is causing a world-wide crisis. (World Commission on Environment and Development, WCED, Sustainable Development and Water, 1989). The World Health Organization (WHO) has estimated that 1000 cubic meters per person per year is the benchmark level below which chronic water scarcity is considered to impede development and harm human health(Gobaisi, 2000). A few companies and research institutions had studied Water reclamation 
technology and put into practice.(Miller,2006; R Hochstrat et al, 2008; Bar-Zeev et al, 2009). China consumes less than one-quarter of the world average per capita water usage, and has one of the thirteen poorest water resources in the world $(\mathrm{Li}, 2005)$. The shortage of water is a serious problem in China. It was estimated that water supplies fall short of 300-400 million cubic meters every year and $70 \%$ of the river systems are polluted to various extents (Zhang et al., 2008). For example, the Huang He is the second longest river in China and $73 \%$ of the sewage disposed into the river originates from industrial discharge. The direct economic loss caused by waste water has reached 1.8 to 2.5 billion USD per year (Ding, 2011). It is well known that water shortage is one of the most important challenges to mankind in this century (Zhang, 2004).

Water conservation contributes to sustainable development and market competitiveness of the food industry. Implementation of water conservation and reuse practices in the food industry faces a great challenge for limiting production costs, and maintaining the environment and public health through knowledge, technical expertise and documentation (Casani et al., 2005; Katherine et al., 2001). The Codex Committee on food hygiene proposed guidelines in 2001 for the hygienic processing of reclaimed water in food plants (Codex Alimentarius Commission, 2001), which is a widely accepted standard for water reclamation in food industries. Richard evaluated the 
public health implications of water reclamation in the food and beverage industry (Richard, 2001), which found that conservative reuse of water had no negative effects on human health. Legislation has been enacted to address water quality, other than drinking water. The US Environment Protection Agency (EPA) in 2004 described guidelines for water reuse. There has been a focus on water reuse technology in canned food factories in Thailand and South Africa. The water reuse rate is greater than $40 \%$ in these countries, which reduces production costs and environmental pollution (Nozaic, 2000; Frankel and Phongsphetraratana, 1986).

Presently, China ranks first in total fruit canning production worldwide, with exports totaling approximately 1.1 million tons per year. China also ranks first in total canned orange output in the world, accounting for $60-70 \%$ of the world's trade volume (Zhang, 2011). Using current processing technologies, the water requirement is quite high, as up to $30-50 \mathrm{~kL}$ of water is required to produce a single metric ton of canned mandarin oranges. The environment could be seriously impacted if wastewater is not properly treated. To make matters even worse, wastewater from canning mandarin oranges contains large amounts of organic components, including carbohydrates, acids, pectin, pigments, and essential oils. The biochemical oxygen demand (BOD) is about $6.4 \mathrm{~kg} / \mathrm{ton}$ and liquid suspensions account for approximately $1.3 \mathrm{ppt}$ of water (Wang et al., 2006). Treatment of this 
type of wastewater is both complex and difficult, and the cost is expected to be very high.

Since there is a higher standard for the safety of food products, water treatment in the food industry must address the potential toxicity of disinfectants and microbiological contamination (Casani et al., 2005). Casani and Knøchel (2002) proposed a Hazard Analysis and Critical Control Points (HACCP)-based approach for evaluating microbiological contamination to ensure acceptable water quality for different purposes when reusing water from the food industry.

To conserve water in the mandarin orange canning industry, a water reclamation system was designed using a production scale of $50,000 \mathrm{~L}$ of water per hour. This project commenced in 2008, some technological improvements and upgrades were introduced, they included following: Sump inlet located stainless steel mechanical grid, which used to intercept pollutants in suspension or floating state; Parallel in the original bag filter on the basis of a set of bag filters, each set of bag filter was used in rotation every 12 hours., then the bag filter can be cleaned regularly; Between the bag filters and activated carbon filter, and between activated carbon filter and UV filter set pressure pump, then the water can be smoothly driven flow through the water treatment system. Its trial run over two production seasons indicated that the quality of reclaimed water met the designated 
requirements.

\section{Materials and Methods}

\subsection{Water reclamation treatment}

The basic processing steps of mandarin orange canning factories were similar to typical canning operations, which included raw material selection, washing, peeling/preparation, blanching, sorting/grading, filling, sealing, retorting, cooling, labeling or storage (Ramaswamy. $\mathrm{H}$ and Michèle $M, 2006)$. The discharged water from these different steps largely varied in quality and quantity. The processing of sorting/grading accounted for 55\% of the total water consumption, but the other processing, which include washing, peeling/preparation, blanching, filling, sealing, retorting, cooling, only for $45 \%$ (Wang,2006). A conveyor belt was use to transport of fruit in the processing of sorting/grading. Great deal of the fresh water emptied into the conveyor belt and discharged. This discharged water was selected for reclamation. As shown in Figure 1, the discharged water from mandarin orange transportation over a conveyor belt was collected in a pool. After chlorination, active carbon filtering and ultraviolet (UV) sterilization, water was reused for blanching, segmenting, transportation, and washing following alkaline solution treatment. The investment cost of this water reuse treatment 
system was about $\$ 460,000$ and the operational cost was approximately $\$ 52,000$ per production season. Six water quality monitoring points were selected in the system for research purposes.

Three $350 \mathrm{~mL}$ water samples were collected at each monitoring point every 4 hours during each sampling date and conducted continually throughout the production season. The samples were analyzed in the factory laboratory immediately after collection. The results were reported as means with standard deviations. 


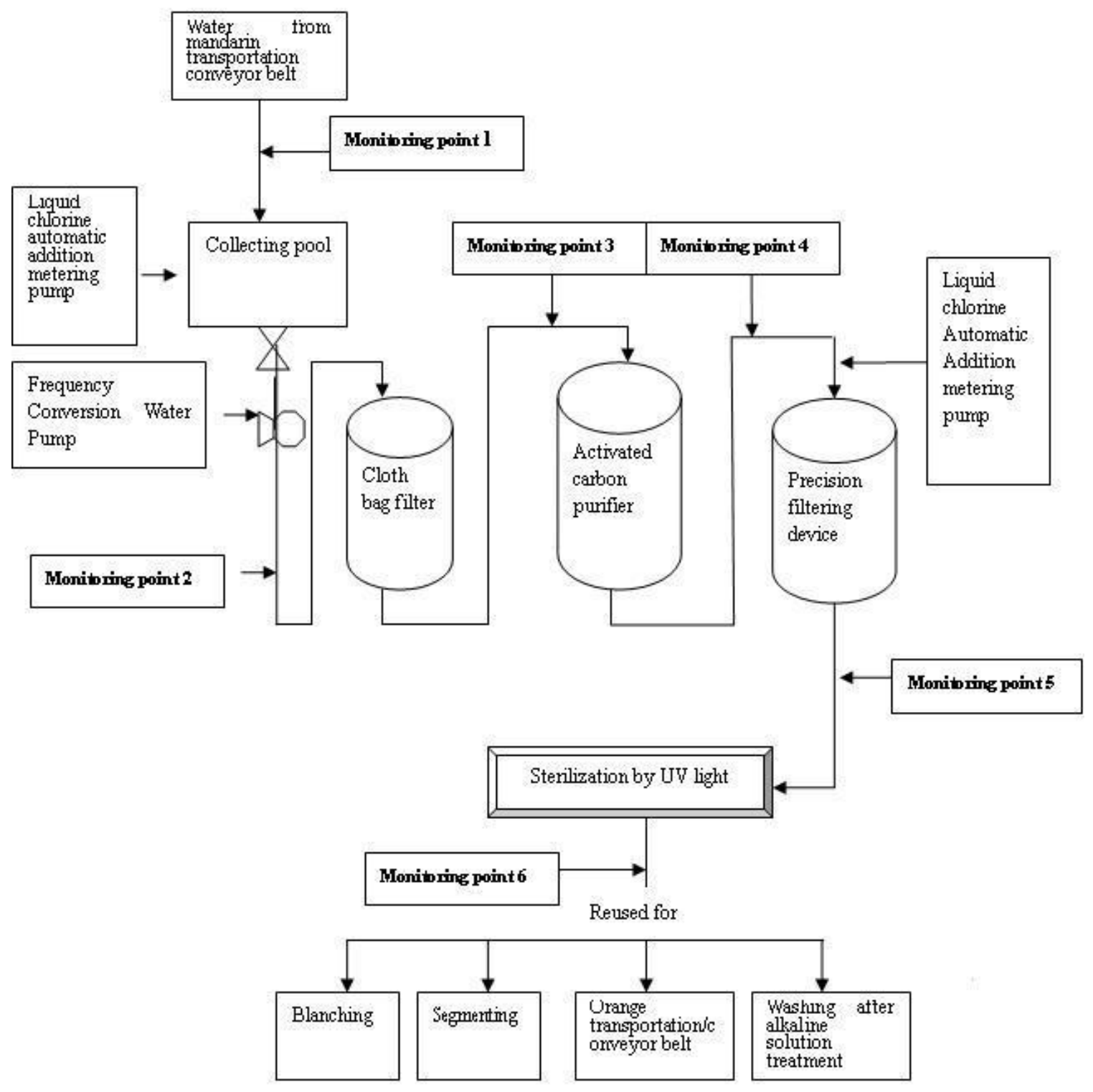

Figure 1 . The water reclamation system and monitoring points in a mandarin orange canning factory

\subsection{Analytical methods}

The water quality parameters of chloride content, pectin content, total bacterial count, E. Coli and coliform bacteria, and physicochemical 
parameters of turbidity, chemical oxygen demand (COD), color, perceivable material, total soluble solids and $\mathrm{pH}$ were selected for analysis.

The chloride content in the samples was determined using a waterproof ExStik CL200 Chlorine Meter (Shanghai San-Xin Instrumentation, Inc. Shanghai, China). The total bacterial count was determined according to the plate count method, and the E. Coli and coliform bacteria contents using the Petrifilm ${ }^{\mathrm{TM}}$ method, as described in the literatures of China's Ministry of Public Health GB/T4789.2 and GB/T4789.3

The pectin content in the water samples were determined by the carbazole and sulphuric acid spectrophotometric method (Pochinok et al., 1976) using a Shimadzu UV2550 spectrophotometer (Shimadzu Scientific Instruments, Columbia, MD, USA).

The physicochemical wastewater parameters of turbidity, color, perceivable material, total soluble solids and $\mathrm{pH}$ were determined according to the National Standard Method of Drinking Water Standard Test Methods, Sensory Characteristics and Physical Indicators (Chinese National Accreditation Service for Conformity Assessment, GB/T 5750.4). The COD was determined according to the Standard Examination Methods for Drinking Water (Chinese National Accreditation Service for Conformity Assessment, GB/T 5750.7). 


\section{Results and Discussion}

\subsection{The residual chloride content in the water reclamation system}

The residual chloride contents from monitoring points in the water reclamation system during the canning process are presented in Figure 2. The water obtained from monitoring point 1 was polluted, whereas water at monitoring point 6 was cleaned following treatment. The former had a lower chloride concentration compared with the latter. The untreated water (monitoring point 1) was obtained from the conveyor belt, which was directly supplied to the factory through a long pipeline from the commercial water company, and the chloride content was less than $0.30 \mathrm{ppm}$. After treatment, the chloride content (monitoring point 6 ) ranged from 0.30 to 0.40 ppm, which met the free chlorine requirement on disinfectants as set by the Chinese National Standard (GB5749-2006, Table2). The residual chloride content at monitoring point 2 was relatively high (1.5 ppm), mainly because of chlorination treatment. The cloth bag filter had little influence, and the chloride levels at monitoring point 3 were almost the same as that of monitoring point 2 . When the water flowed through the activated carbon purifier (monitoring point 4), the level of residual chloride decreased sharply by approximately $70 \%$. The activated carbon purifier's tank was $2600 \mathrm{~mm}$ in 
diameter and $1500 \mathrm{~mm}$ in height, that stored $5 \mathrm{~kL}$ of filtration material of core absorbent carbon. It is designed for a production scale of $50 \mathrm{~kL} / \mathrm{h}$. The activated carbon had a good adsorption capacity for residual chloride in water, and its efficiency was primarily dependent on the residual chloride concentration (Voudrias et al., 1985). To inhibit microbial growth, a second chlorination unit was added, and the level of residual chloride remained at about $1.0 \mathrm{ppm}$ (monitoring point 5). However, the chloride concentration decreased when the water flowed through the UV sterilization device at monitoring point 6 , which reduced the remaining chloride by more than $60 \%$. The UV sterilization device was made up of three ultraviolet sterilizers, all of them were in parallel. Each ultraviolet sterilizer was designed for a production scale of $16--20 \mathrm{~kL} / \mathrm{h}$, which nominal capacity was $220 \mathrm{w}$. It was $219 \mathrm{~mm}$ in diameter and $1200 \mathrm{~mm}$ in length, the input pipe diameter was $80 \mathrm{~mm}$. UV treatment is very effective for chloride degradation, which is dependent on light intensity and treatment duration (Huff et al., 1965). 


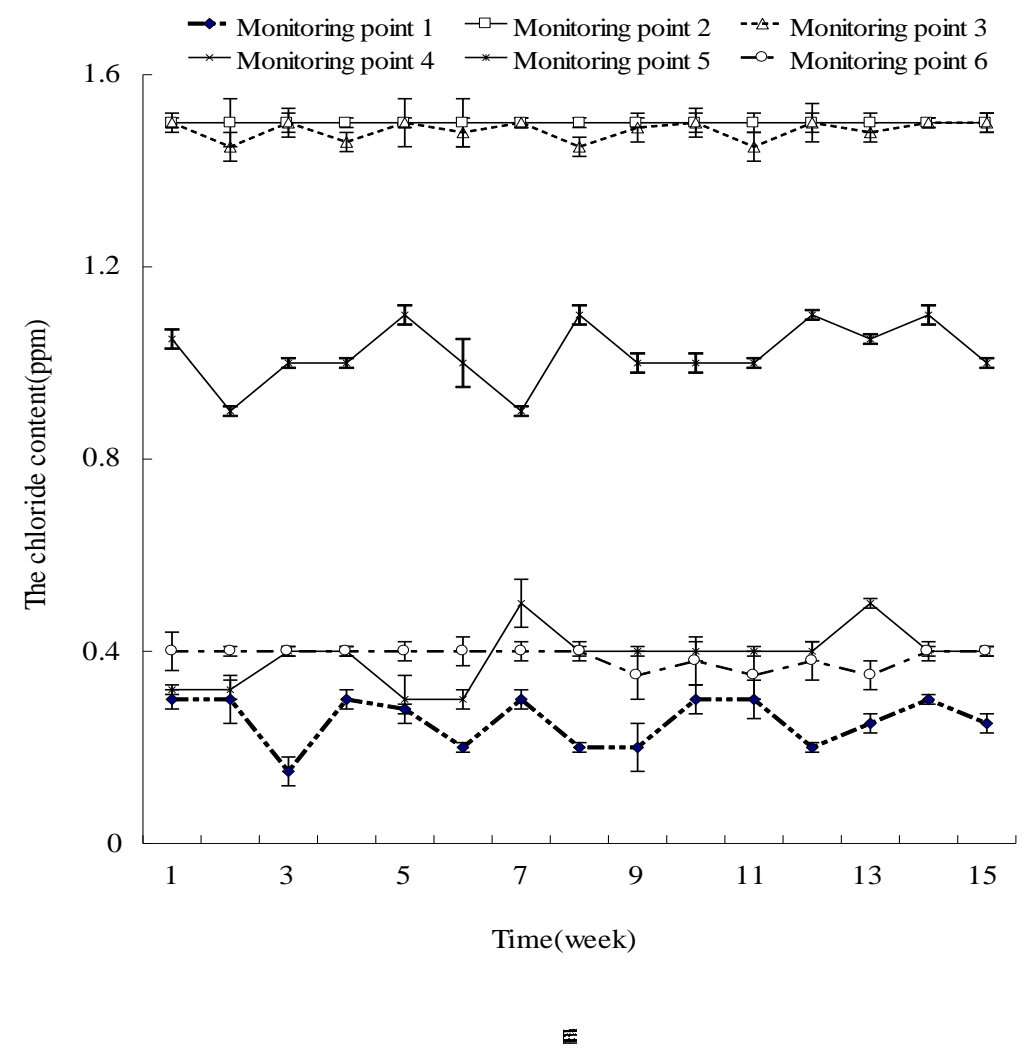

EFigure 2. Residual chloride contents at monitoring points in the water reclamation system.

\subsection{Total bacterial count and $E$. coli in the water reclamation system}

The total bacterial count and E. coli detected at various monitoring points in the water reclamation system during operation are presented in Figures 3 and 4. Water samples obtained from monitoring point 1 contained between 10 and $100 \mathrm{CFU} / \mathrm{mL}$, while the concentration of E. coli was less than $10 \mathrm{CFU} / \mathrm{mL}$. Microbial contamination was virtually unavoidable, because the fruit was manually handled during transportation along the conveyor belt. Furthermore, considerable amounts of organic compounds 
from mandarin orange segments might have been dissolved in the water, which offered nutrients for microorganism growth. Following the chlorination treatments, the total bacterial count and E. coli content of water samples at monitoring points 2 and 5 decreased to less than $1 \mathrm{CFU} / \mathrm{mL}$, suggesting a good disinfection effect. At monitoring point 6 , the total bacterial count averaged less than $1 \mathrm{CFU} / \mathrm{mL}$ and the $E$. coli was not detected in the water after the reclamation process, which met the Chinese National Standard (Standards for Drinking Water Quality, GB5749-2006, Table 1).

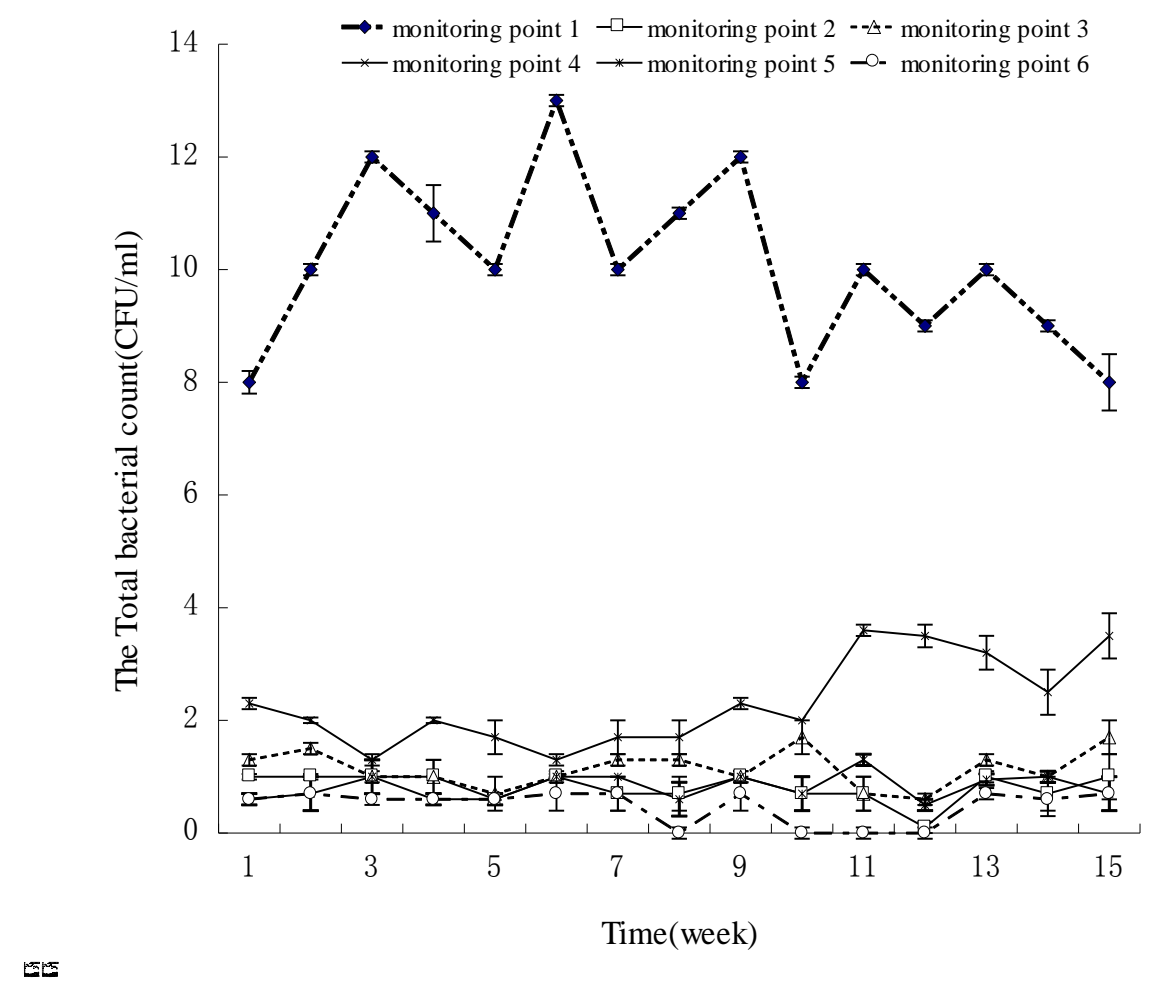

Figure 3. The total bacterial count at six monitoring points in the water reclamation system of a mandarin orange caning factory. 


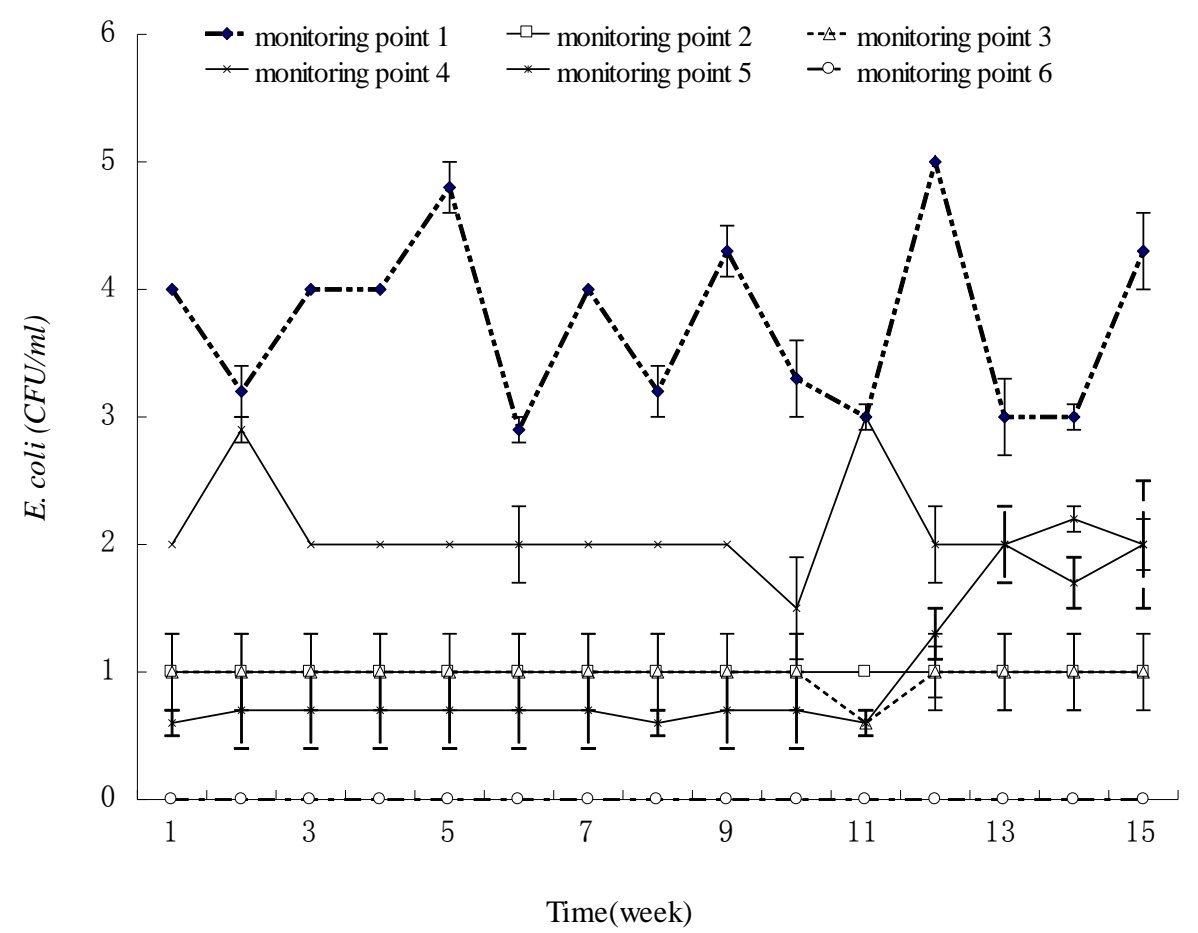

Fig. 4. E. coli detection at six monitoring points in the water reclamation system of a mandarin orange caning factory.

\subsection{Changes in pectin content in the water reclamation system}

The pectin content of water samples from the water reclamation system was presented in Figure 5. Monitoring showed that water from the conveyor belt (monitoring point 1) contained the highest amount of pectin (27 ppm), and then gradually decreased as the water passed through the system. Following activated carbon adsorption, the pectin content was reduced to $13.36 \mathrm{ppm}$ (monitoring point 4 in Figure 5). The cleaned water (monitoring point 6) contained approximately $10 \mathrm{ppm}$ of pectin, but did not induce cloudiness in the water, and didn't have any negative influences on 
processing the canned fruit.

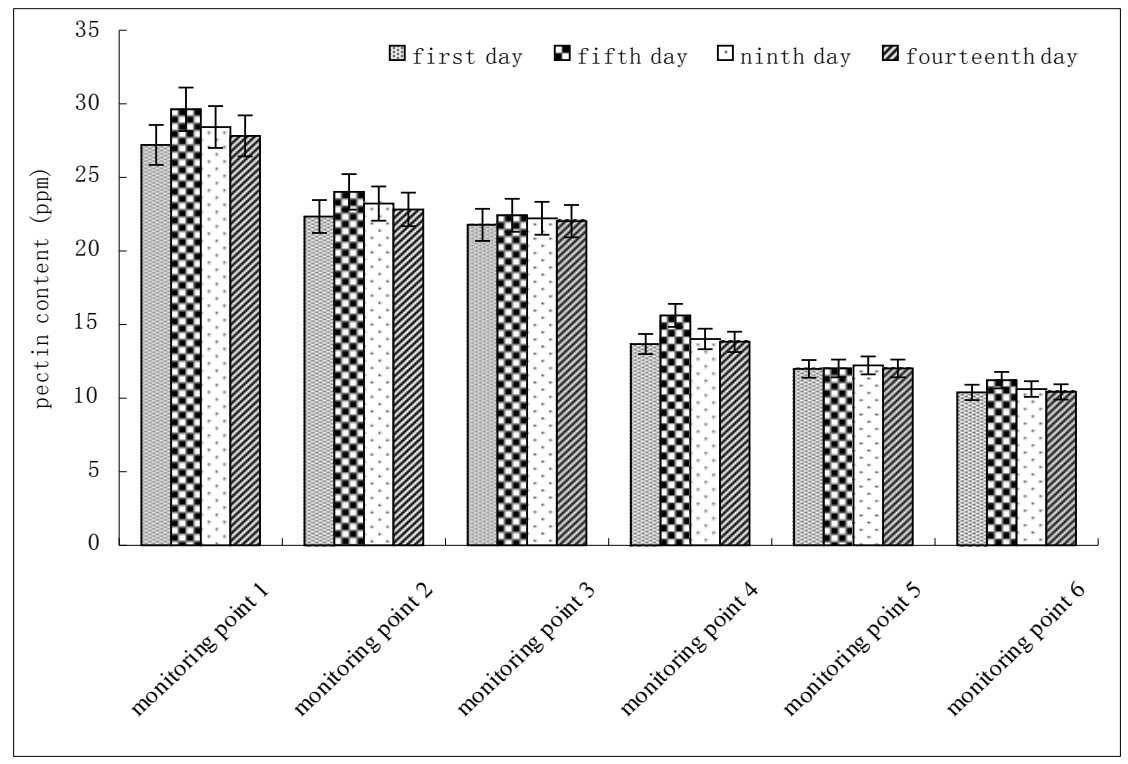

Figure 5. Pectin content at six monitoring points in a water reclamation system in a mandarin orange caning factory.

\subsection{Changes in other physicochemical parameters in the water} reclamation system

The changes of other physicochemical water parameters for the water reclamation system were presented in Table 1 . Before treatment, water at monitoring point 1 had a chroma value of 12 Hazen units (HU), turbidity of 6.3 NTU (nephelometric turbidity unit), and total soluble solids of $157 \mathrm{mg} / \mathrm{L}$. However, water after treatment (monitoring point 6) had a chroma value of 4 HU, turbidity of $2.8 \mathrm{NTU}$ and total soluble solids less than $100 \mathrm{mg} / \mathrm{L}$. The data showed that the sensory index improved significantly after the water passed through the reclamation system. The $\mathrm{pH}$ values of the water were 
maintained within the range of 6.4 to 6.9 , which met the Chinese National Standard (Table 1). The water was clear and no abnormal smell was detected. The processed water physicochemical parameters of turbidity, color, perceivable material, total soluble solids and $\mathrm{pH}$ met the Chinese National Standard (GB 5749-2006).

The COD value $(52 \mathrm{mg} / \mathrm{L})$ was notably higher than that of the Chinese National Standard, which may have been caused by dissolved pectin in the water (Wang, 2008; Garcia-Castello et al., 2011). Pectin is a constituent of oranges, therefore a high COD value might not be a concern for the safety and quality of the canned mandarin processing, providing the microorganisms were well controlled (section 3.2). The COD values indicate organic pollution levels in water. Many studies on organic pollution in water treatment have addressed biochemical treatments (Verma et al., 2006; Alfea et al., 2007; Ginkel et al., 2005; Zhu, 2004), while few have reported that the COD value was sufficiently controlled within the range of $100 \mathrm{mg} / \mathrm{L}$, if the wastewater hadn't been biochemically treated. Soluble components of the raw material were easily dissolved in water during the production process. The water COD value of the present reclamation system reached about 52 $\mathrm{mg} / \mathrm{L}$, which illustrated its efficiency in water quality improvement.

Table 1. Changes in physicochemical water parameters during water reclamation 


\begin{tabular}{|c|c|c|c|c|c|c|c|}
\hline monitoring point & $\begin{array}{c}\text { Turbidity } \\
\text { (NTU) }\end{array}$ & $\underset{\left(\mathbf{m g} \cdot \mathbf{L}^{-1}\right)}{\text { COD }}$ & $\begin{array}{c}\text { Chroma } \\
\text { (HU) } \\
\text { (platinum - } \\
\text { cobalt color) }\end{array}$ & $\begin{array}{c}\text { Perceivable } \\
\text { material }\end{array}$ & Odor & $\begin{array}{c}\text { Total soluble } \\
\text { solids } \\
\text { mg.L } \mathrm{L}^{-1}\end{array}$ & pH \\
\hline 1 & 6.3 & 298.73 & 12 & many & Slight odor & 157 & 6.56 \\
\hline 2 & 5.8 & 112.36 & 10 & little & Slight odor & 96 & 6.85 \\
\hline 3 & 5.5 & 91.07 & 8 & little & Slight odor & 75 & 6.88 \\
\hline 4 & 4.1 & 89.65 & 6 & None & None & 61 & 6.42 \\
\hline 5 & 3.9 & 70.85 & 5 & None & None & 80 & 6.45 \\
\hline 6 & 2.8 & 52.46 & 4 & None & None & 93 & 6.70 \\
\hline $\begin{array}{c}\text { Chinese National } \\
\text { Standard(maximum } \\
\text { values) } \\
\end{array}$ & 3 & 3 & 15 & None & None & 1000 & $6.5 \sim 8.5$ \\
\hline
\end{tabular}

Note: Turbidity, COD, Chroma, Total Soluble Solids and $\mathrm{pH}$ were measured on-line.

\section{Conclusions}

A water reclamation system was designed for a mandarin orange canning factory with a production rate of 50,000 L/h. From the mandarin processing line, the water from a conveyor belt area was collected and treated by chlorination, active carbon filtration and UV sterilization. The water after reclamation was clear, with most of the physicochemical parameters meeting the Chinese National Standard (GB5749-2006). Reclaimed water could then 
can be reused for mandarin grading, segmenting, conveying, and washing following alkaline treatment. This system can save $100,000 \mathrm{~L}$ of water per hour, which equates to $840,000,000 \mathrm{~L}$ of water that can be saved over one production season ( 8 hours/day and 105 days/production season). As water is a very important, but scarce, resource in China and around the world, this water reclamation system could be a practical and economical approach in other fruit and vegetable canning factories.

\section{Acknowledgements}

This project was financially supported by China high-tech research programs (ID: 2011AA100804, 2012BAD31B06 \& SQ2012ECC220013) and Zhejiang Province project (ID:2010R50032, 2010C12020-2).

\section{References}

(1) A.Fahnrich, V. Mavrov and H. Chmiel, Membrane process for water reuse in the food industry,Desalination.,119(1998) 213-216.

(2) B.W. Wang, D. Zhen, M.C. Zhao, et al., Modern natural geography, Science Press,Beijing 2008,pp 2.

(3) C. B.Huff, H. F.Smith, W. D.Boring, et a1., Study of ultraviolet disinfection of water and factors in treatment efficiency, Public Health 
Reports, 80(1965) 695-706.

(4) C.Sandra , R. Mahbod and Knochel. Susanne, A discussion paper on challenges and limitations to water reuse and hygiene in the food industry, Water Research, 39(2005)1134-1146.

(5) C.Wang, C.J. Bai and A.B He, Wastewater treatment in mandarin orange canning factory of ZheJiang Province. Science and technology information, 12 (2006)24-25.

(6) Codex Alimentarius Commission, Codex committee on food hygiene. proposed draft guidelines for the hygienic reuse of processing water in food plants. Joint FAO/WHO Food Standards Programme, 34th Session, Bangkok, Thailand, 2001.

(7) D.Al Gobaisi, Sustainability of desalination systems, Invited lecture, Euro Course on Desalination Sustainable Development, Lisbon, 2000.

(8) D.S. Zhang, Applications of membrane technology in water saving and environment protection during food processing, Science and technology of food industry, 11(2004)158-160.

(9) DJ. Nozaic, Risk and safety associated with the reuse of food processing water. Water Reuse Symposium. Pretoria, South Africa, 2000.

(10) E. Bar-Zeev, I. Berman-Frank, B. Liberman, E. Rahav, U. Passow and T. Berman. Transparent Exopolymer Particles; Potential Agents for Organic Fouling and Biofilm Formation in desalination and Water treatment 
Plants. Desalination and Water Treatment.3,136-142,2009

(11) E.A.Voudrias, R.A. Larson, and V. L.Snoeyink, Effects of activated carbon on the reactions of free chlorine with phenols. Environmental Science and Technology, 19 (1985) 441-449.

(12) E.M.Garcia-Castello cor1, L.Mayor, S.Chorques, et a1., Reverse osmosis concentration of press liquid from orange juice solid wastes: Flux decline mechanisms, Journal of Food Engineering, 106 (2011) 199-205.

(13) F. Zhang, Analysis of the Trading Situation of fruit Industry in China in 2010, China fruit news, 28(2011) 1-9.

(14) F.Y. Wang, Study on the degradation of the pectin in wasterwater from the production of mandarin canning factory by pectinase, Master Thesis, ZheJiang University, 2008.

(15) GB 5749-2006, China National Standard for drinking water quality.

(16) GB/T4789-2008, Microbiological examination of food hygiene

(17) GB5750-2006, Standard examination methods for drinking water.

(18) Guidelines for Water Reuse, 625/R-04/108, US Environment Protection Agency, Washington DC, USA. 2004.

(19) H.Katherine, S.Ann, S. Miranda and H.Stefan, The challenge of waste minimisation in the food and drink industry: a demonstration project in East Anglia, UK. Journal of Cleaner Production, 9 (2001)57-64. 
(20) Hosahalli R. and Michèle M.Food Processing:Principles and Applications.CRC Press. Taylor \& Francis Group, LLC.NW..USA. 2006,pp111-126

(21) M. Verma, S.K. Brar and J.F. Blais, Aerobic biofiltration processes advances in wastewater treatment. Practice Periodical of Hazardous, Toxic, and Radioactive Waste Management, 10(2006)264-276.

(22) Miller,G.W., 2006. Integrated concepts in water reuse:managing global water needs. Desalination, 187(1-3):65-75

(23) Q.Li, Chinese water question. Princeton University Press,Beijing 2005,pp.2

(24) R Hochstrat, T Wintgens, T Melin, Development of integrated water reuse strategies, Desalination, Volume 218, Issues 1-3, 5 January 2008, Pages 208-217

(25) R.Alfea, Upadhyay, K.Virendra, et a1., Biofiltration of secondary treated municipal wastewater in a tropical city, Ecological engineering, $30(2007) 9 \sim 15$.

(26) R.J. Frankel, A. Phongsphetraratana, Effects of water reuse, recycling and resource recovery on food processing waste treatment in Thailand, Water Science and Technology, 18(1986).23 33.

(27) S. V.Ginkel, S.E.Oh and B. E.Logan, Biohydrogen production from food processing and domestic wastewaters, Int. J. Hydrogen Energy,30 
(2005)535-1542.

(28) S.Casani , M. Rouhanyb, S.A.Knøchel, Discussion paper on challenges and limitations to water reuse and hygiene in the food industry, Water Research, 39(2005)1134-1146.

(29) S.Casani, S.Knøchel, Application of HACCP to water reuse in the food industry, Food Control, 13 (2002)315-327.

(30) S.Y. Jia , X.M.Wang, G.G. Liu, et al., Research for the treating technology of the wastewater in pectin production by chemical coagulating method, Journal of north china institute of technology, 22(2001)50-53.

(31) UN. Water development and management, Proceeding of UN.Water Conference 1977, part 4. Oxford: Program on Press, 1978.

(32) W.X.Ding, Strategy and recommendations on sustainable development of water resources in China, Chinese Agricultural Science Bulletin, 27(2011) 221-226.

(33) WCED.Sustainable Development and Water, Statement on the WCED Report“Our Common Future”. Water International, 14(1989),151-152.

(34) X.N.Pochinok, J.H.Jing and Z.R.Ding, Analysis methods for plant biochemistry. Science Press,Beijing1976, pp. 166-173.

(35) C. Richard . Public health implications of water reuse in the food and beverage industry, ILSI Seminar, ee-use of process water in the food and 
beverage industries: Pretoria, South Africa, 2000(Available online at: http://southafrica.ilsi.org/file/Water_Re-use_symp_Carr_paper.pdf). (36) Z.B.Zhang, P.Xu, Water and food security in China, Chinesed Journal of Eco-Agriculture, 16(2008)305-1310.

(37) Z.B.Zhu, Review: the research progress of organic wastewater treatment, Journal of chemical industry \& engineering, $25((2004) 50-53$. 